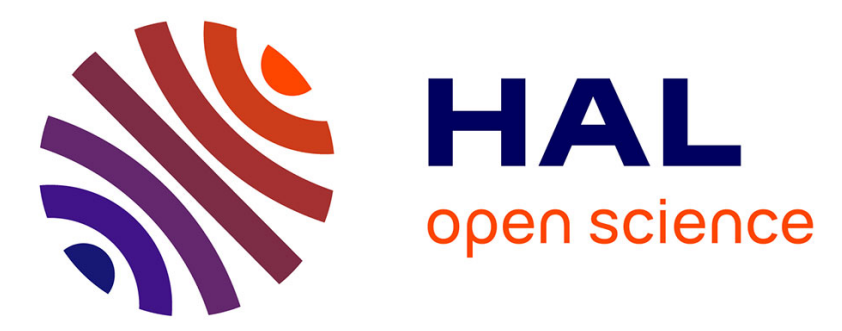

\title{
New 92S6 mesoporous glass: Influence of surfactant carbon chain length on the structure, pore morphology and bioactivity
}

Nouha Letaïef, Anita Lucas-Girot, Hassane Oudadesse, Rachida Dorbez-Sridi

\section{- To cite this version:}

Nouha Letaïef, Anita Lucas-Girot, Hassane Oudadesse, Rachida Dorbez-Sridi. New 92S6 mesoporous glass: Influence of surfactant carbon chain length on the structure, pore morphology and bioactivity. Materials Research Bulletin, 2014, 60, pp.882-889. 10.1016/j.materresbull.2014.08.048 . hal01072536

\section{HAL Id: hal-01072536 https://hal.science/hal-01072536}

Submitted on 8 Oct 2014

HAL is a multi-disciplinary open access archive for the deposit and dissemination of scientific research documents, whether they are published or not. The documents may come from teaching and research institutions in France or abroad, or from public or private research centers.
L'archive ouverte pluridisciplinaire HAL, est destinée au dépôt et à la diffusion de documents scientifiques de niveau recherche, publiés ou non, émanant des établissements d'enseignement et de recherche français ou étrangers, des laboratoires publics ou privés. 


\title{
New 92S6 mesoporous glass: Influence of surfactant carbon chain length on the structure, pore morphology and bioactivity
}

\author{
N. Letaief ${ }^{\mathrm{a}, \mathrm{b}}$, A. Lucas-Girot ${ }^{\mathrm{a}}, \mathrm{H}$. Oudadesse ${ }^{\mathrm{a}}$, R. Dorbez-Sridi ${ }^{\mathrm{b}}$
}

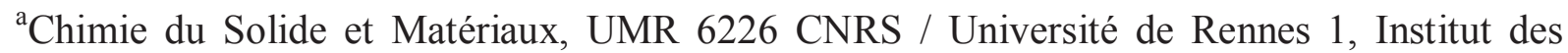
Sciences Chimiques de Rennes, Campus de Beaulieu, Avenue du Général Leclerc, 35042 Rennes Cedex, France.

${ }^{b}$ Laboratoire de Physico-Chimie des Matériaux, Département de Physique, Faculté des Sciences de Monastir, Avenue de l'environnement, 5019 Monastir, Tunisie.

Corresponding author(s): nouha_If@yahoo.fr, Téléphone: +33753762022

\section{Graphical abstract}

\begin{abstract}
:
The main objective of the present work was to investigate the effect of surfactant chain length on the structure, porosity and bioactivity of $92 \mathrm{~S} 6\left(92 \% \mathrm{SiO}_{2}, 6 \% \mathrm{CaO}\right.$, and $\left.2 \% \mathrm{P}_{2} \mathrm{O}_{5} \mathrm{~mol} \%\right)$ mesoporous sol-gel glasses. The aim was to provide a basis for controlling the porosity of the glass to obtain a control of bioactive behavior.

A series of mesoporous bioactive glasses were synthesized using three different surfactants $\left(\mathrm{C}_{10} \mathrm{H}_{20} \mathrm{BrN}, \mathrm{C}_{19} \mathrm{H}_{42} \mathrm{BrN}, \mathrm{C}_{22} \mathrm{H}_{48} \mathrm{BrN}\right)$.
\end{abstract}

Surfactant type dependence on the textural properties, particularly porosity and bioactivity were studied.

Results indicate that bioactivity factors were improved by a short surfactant carbon length.

Keywords: A. amorphous materials, B. sol-gel chemistry, C. X-ray diffraction, C. electron microscopy, A. glasses.

\section{Introduction}

Various kind of bioactive materials like hydroxyapatite, bioglasses, bioglass-ceramics and calcium phosphate ceramics have attracted a strong interest of research over the last decades 
and have shown significant potential in biomedical research field. These glasses facilitate bone integration of the implant [1], they are also intended to replace bone through a bone defect area in the human skeleton $[2,3]$. The bioactive behavior of these glasses, which is identified as capability of bone bonding, is attributed to the formation of an apatite-like layer, whose composition and structure are equivalent to the mineral phase in bone [4].

Two methods were suggested for the preparation of bioactive glasses: melting and sol-gel methods. Sol-gel process enables to obtain a wide range of compositions with high purity, homogeneity and production of various shapes; such as monoliths, powders or fibers [5]. Additionally, it is well established that sol-gel glasses have higher ability to induce hydroxyapatite formation than melt derived glasses [6]. Sol-gel technique has many advantages with respect to the control of material's surface chemistry which is directly related to the bioactive behavior [6]. The major differences in surface between sol-gel and melt derived glasses are: (i) sol-gel glass has a higher specific surface area ii) sol-gel glass has a larger pore volume on the surface; and (iii) sol-gel glass has a larger concentration of silanols groups $(\mathrm{Si}-\mathrm{OH})$ on the surface [1]. All these surface chemistry and textural properties induce better bioactive behavior than conventional melt-derived glass.

In the last couple of decades, there has been some interest in porous glasses in applications where bone ingrowth is needed or as coatings in applications such as implants, where a good bone-implant interface is required [7,8]. Porous biomaterials have been produced by several techniques such as the use of polymeric sponge, foaming processes and techniques using organic surfactants such as $n$-hexadecyltrimethylammonium bromide CTAB [7].

The porous structure is induced by the condensation of silica around supramolecular surfactant aggregates acting as a structure-directing agent, and the pores are formed upon removal of the surfactant from the matrix by calcination [9]. One of the advantages with templated mesoporous materials is that they exhibit a narrow pore size distribution in 
combination with a high pore volume. The resulting amorphous material is biocompatible [9]. It's well known that a bioactive material is one that elicits a specific biological response at the material interface and allows the attachment to the tissue, such as soft tissue and bone [2]. When bioactive materials are implanted in human body, their interface is transformed to a calcium phosphate phase (apatite phase) through of series of surface reactions including ion exchange and dissolution-precipitation reactions denoted as "bioactive process" [3]. Subsequently, the implants were integrated to living bone [5]. This mechanism does not depend on the presence of living tissues and occur even when the glasses are soaked in simulated body fluids. In vivo studies revealed that bioactive glasses show no local or systemic toxicity, no inflammation, and bond to tissues without encapsulation by fibrous layer $[5]$.

For bioactive glasses, variables such as chemical composition, structure, surface morphology, and synthesis conditions, such as temperature, $\mathrm{pH}$, and reactant ratios, are influent parameters on the bioactivity $[6,10-15]$. All these factors must be taken into account when applying this synthesis route to biomaterials, as the bioactive process is a surface process and the response of the living tissue will be ruled by the surface characteristics of the implant $[16,17]$.

The objective of this paper is to report the preparation of mesoporous glasses in the system $\mathrm{SiO}_{2}-\mathrm{CaO}-\mathrm{P}_{2} \mathrm{O}_{5}\left(92 \% \mathrm{SiO}_{2}, 6 \% \mathrm{CaO}\right.$, and $2 \% \mathrm{P}_{2} \mathrm{O}_{5}$ mol \%), named 92S6, through sol-gel route. In order to analyze changes in $92 \mathrm{~S} 6$ textural properties, synthesized using different carbon-chain-length, and in order to estimate the values of parameters describing the properties of pore structure, X-ray diffraction studies and nitrogen adsorption isotherms were used. In vitro bioactivity of glasses was investigated to analyze its feasibility as biomaterial.

\section{Experimental method}

\subsection{Preparation of mesoporous bioactive glass samples (92S6)}

\subsubsection{Reactants}


Tetraethyl orthosilicate (TEOS) (99\%; Aldrich, France) was used as a silica source, Triethyl phosphate (TEP) (99.8\%; Aldrich, France) was used as source of phosphorous, calcium carbonate $\mathrm{CaCO}_{3}\left(>98.5 \%\right.$; Merck, France) was used as source of calcium. $\mathrm{C}_{10} \mathrm{H}_{20} \mathrm{BrN}(97 \%$; Alfa Aesar, Germany), $\mathrm{C}_{19} \mathrm{H}_{42} \mathrm{BrN}$ (98\%; Alfa Aesar, Germany) and $\mathrm{C}_{22} \mathrm{H}_{48} \mathrm{BrN}$ surfactants (80\%; Alfa Aesar, Germany) were used as a structure-directing agent. Water was used as solvent. All materials were used as received without further purification.

\subsubsection{Synthesis procedure}

Samples were prepared by the sol-gel process. The synthesis was carried out according to the modified Stöber's method described for synthesis of monodisperse silica spheres MCM-41 [18]. In the first step, the solution was prepared as follows: $2.5 \mathrm{~g}$ of commercial surfactant $\left(\mathrm{C}_{10} \mathrm{H}_{20} \mathrm{BrN}, \mathrm{C}_{19} \mathrm{H}_{42} \mathrm{BrN}, \mathrm{C}_{22} \mathrm{H}_{48} \mathrm{BrN}\right)$ was dissolved in $50 \mathrm{~mL}$ of deionized water and mixed with $75 \mathrm{~mL}$ of absolute ethanol, at room temperature. $3.6 \mathrm{~g}$ of TEOS is further added to this solution and kept under strong stirring for one hour. Under stirring, $0.16 \mathrm{~g}$ of TEP and an acidic $\mathrm{CaCO}_{3}$ solution were added. In the second step, the mixture was stirred for 24 hours at $20^{\circ} \mathrm{C}$. Finally $18.53 \mathrm{~mL}$ of aqueous ammonia solution ( $25 \% \mathrm{wt}$, Fluka, France) was added to this clear solution and stirred for $15 \mathrm{~min}$. At the end of the addition of aqueous ammonia solution, the gel formation immediately began. The white precipitate was isolated by filtration and washed several times with water and ethanol until neutral $\mathrm{pH}$ was reached.

\subsubsection{Calcination}

The samples were dried at $90^{\circ} \mathrm{C}$ overnight. The surfactant was removed by calcination, treating the dried gel at $650^{\circ} \mathrm{C}$ for $6 \mathrm{~h}$. The resulting bioactive glass was crushed and sieved to select grain size less than $63 \mu \mathrm{m}$. Samples were then characterized.

Materials are named as 92S6-C7, 92S6-C16 and 92S6-C19 according to the number of carbons of the surfactant tail.

\subsection{Samples characterization}


The wide angle X-ray diffraction (WAXRD) patterns of the samples were recorded on a Bruker AXS diffractometer with monochromatized $\mathrm{CuK}_{\alpha}$ radiation $(\lambda=1.5406 \AA)$, operating at $40 \mathrm{kV}, 40 \mathrm{~mA}$, with $0.02^{\circ}$ step size and a counting time $300 \mathrm{~ms}$ per step, over a range of $5^{\circ}<$ $2 \theta<80^{\circ}$, at room temperature.

Scanning electron microscopy (SEM) was performed on a JEOL-JSM-6301F instrument. Specific surface area and pore size distribution of the materials were determined by nitrogen $\mathrm{N}_{2}$ adsorption-desorption using a Micromeritics ASAP-2010. Both the adsorption and desorption branches of the isotherms were analyzed. From these data the specific surface area and the pore size distribution of the samples were calculated. The pore size distribution was determined using the BJH method (desorption) [19].

\subsection{In vitro bioactivity test}

The HAP-forming ability of the glass powder was analyzed by immersing the samples in simulated body fluid (SBF) for various periods of time. Each specimen was immersed in SBF solution at $37 \pm 0.5^{\circ} \mathrm{C}$, for $7,15,21$ and 30 days. This solution has ion concentrations and $\mathrm{pH}$ nearly equal to those of human blood plasma. The glass specimen before soaking in SBF is termed as zero days' specimen. The SBF was prepared by dissolving reagent-grade $\mathrm{NaCl}$; $\mathrm{KCl} ; \mathrm{NaHCO}_{3} ; \mathrm{MgCl}_{2}, 6 \mathrm{H}_{2} \mathrm{O} ; \mathrm{CaCl}_{2}$ and $\mathrm{KH}_{2} \mathrm{PO}_{4}, 3 \mathrm{H}_{2} \mathrm{O}$ in deionized water. The solution was buffered at $\mathrm{pH}=7.4$ with Tris-(hydroxymethyl)-aminomethane $\left(\left(\mathrm{CH}_{2} \mathrm{OH}\right)_{3} \mathrm{CNH}_{3}\right)$ and hydrochloric acid according to Kokubo's protocol [20]. A solid to liquid ratio of $1 \mathrm{mg} / 2 \mathrm{ml}$ was maintained for all immersions, and the SBF solutions were not renewed during the experiments.

The samples were removed from the incubator, rinsed with deionized water and left to dry at ambient temperature overnight. ICP-OES was used to analyze the ionic composition of SBF after immersion of the glass samples.

\section{Results and discussion}




\subsection{Glasses Characterization}

\subsubsection{Small and Wide X-ray diffraction}

Fig. 1 shows similar Small Angle X-ray diffraction (SAXRD) patterns of the bioactive glasses with the same chemical composition prepared with different cationic surfactants. It can be observed that there is no diffraction peaks appearing on the pattern of the samples prepared with $\mathrm{C} 7, \mathrm{C} 16$ and $\mathrm{C} 19$ surfactants, which suggests that for these samples there is no periodic arrangement of the mesopores.

The powder wide-angle XRD patterns for all samples are shown in Fig. 2. They all exhibit XRay diffraction data characteristic of amorphous materials with no evidence of crystalline phases.

\subsubsection{BET analysis}

Nitrogen isotherms of calcined 92S6-C7, 92S6-C16 and 92S6-C19 are shown in Fig. 3. All samples exhibited isotherms of type IV based on the IUPAC classification.

92S6-C7 and 92S6-C16 glasses exhibited hysteresis loops of H3 type, and for 92S6-C19 glass, it exhibited a $\mathrm{H} 4$ type which is associated with the presence of mesopores. Table 1 summarizes the different pore sizes, specific areas and pore volumes in samples. Synthesized glasses show specific surface area $\left(\mathrm{S}_{\mathrm{BET}}\right)$ in the range of 88 to $248 \mathrm{~m}^{2} \cdot \mathrm{g}^{-1}$. It shows that the use of different surfactants has a significant influence on glass specific area. On the other hand, a decrease of pore volume $(\mathrm{Vp})$ is observed, the value is declined from $0.28 \mathrm{~cm}^{3} / \mathrm{g}$ to $0.13 \mathrm{~cm}^{3} / \mathrm{g}$ with increasing the number of surfactant carbons. The $\mathrm{N}_{2}$ adsorption experiments revealed that these materials have an average pore size varying from $2.6 \mathrm{~nm}$ to $8.24 \mathrm{~nm}$.

As we know, during the sol-gel process the alkoxysilane precursors react easily with water, the hydrolyzed species link together in condensation reactions and form a polymeric network, especially for the tetraethylorthosilicate TEOS. A similar study on the effect of surfactant chain length on the pore diameter of metal oxide-surfactant composite showed that the pore 
size of the synthesized composite is assigned by changing the length of the surfactant tail. For example, in the series $\mathrm{C}_{\mathrm{n}} \mathrm{TMABr}, \mathrm{n}=7,10,12,14,16,19$, the pore size of the as-synthesized material increases about $2.25 \AA$ for each increase of one carbon in the surfactant $[21,22]$.

The explanation for the nature of hysteresis may be that the length of carbon chains plays an important role in the formation of the mesoporous structure [23], and the pore diameter is mainly influenced by the carbon chain length.

These results are associated to the mechanism of formation of these glasses. For example, cetyltrimethylammonium bromide $\left(\mathrm{C}_{16} \mathrm{TMABr}\right)$ in water will form spherical micelles [24]. In the surfactant molecule, the polar hydrophilic head groups form the outer surface, which is in contact with the aqueous phase, and the apolar hydrophobic tails (hydrocarbon chain) point toward the center [25]. So the pore diameter depends critically on the size of hydrophobic groups in the surfactant. When we increase the number of carbons, the hydrophobic part of the surfactant will be composed by a large tail; which results in an increase of pore diameter. So, the increase of the number of carbons results in an increase of pore diameter in glasses prepared with different surfactants.

The $P / P_{0}$ values after inflection point, ranging from 0.40 to 0.95 , confirm the mesoporous characteristic, and the mesopores filling occurs in a slightly larger range of $P / P_{0}$ values, in that the step in the isotherms appears less pronounced. This suggests a lower homogeneity of pore size [26]. Capillary condensation pressure increases as a function of carbons number (Fig. 3). This result confirms that the pore size of glasses can be tailored by a modification of the surfactant.

\subsubsection{Fourier Transform Infrared Spectroscopy (FTIR)}

Fig. 4 reports the FTIR spectra, in the $400-2000 \mathrm{~cm}^{-1}$ spectral range, of the 92S6-C7, 92S6C16 and 92S6-C19 powder surfaces, before soaking in the SBF solution. 92S6-C7 shows the characteristic absorption bands of the silicate vibrations: 465, 807, $1060 \mathrm{~cm}^{-1}$ assigned to Si- 
O-Si bending mode, Si-O-Si symmetric stretching mode of bridging oxygen atoms between tetrahedrons and $\mathrm{Si}-\mathrm{O}-\mathrm{Si}$ asymmetric stretching of bridging oxygen atoms within the tetrahedron, respectively [2]. The band located at $606 \mathrm{~cm}^{-1}$ is attributed to P-O bending band of $\mathrm{PO}_{4}{ }^{3-}$ group in crystal [2]. A weak band appearing as shoulder at $973 \mathrm{~cm}^{-1}$-may be related to $\mathrm{P}-\mathrm{O}$ stretching vibrations in tetracalcium phosphate [27]. The band observed at $1238 \mathrm{~cm}^{-1}$ is related to the presence of $\mathrm{PO}_{4}{ }^{3-}$ groups in the glass structure. For glasses with low content of $\mathrm{P}_{2} \mathrm{O}_{5}$, phosphorous is not considered as a glass former like silicon, but phosphorous is present in the glass structure as $\mathrm{PO}_{4}{ }^{3-}$ ions like a glass modifier [28]. The peaks at 1421 and $1491 \mathrm{~cm}^{-1}$ are assigned to $\mathrm{C}-\mathrm{O}$ vibrations in carbonate $\mathrm{CO}_{3}{ }^{2-}$ group. The band at $673 \mathrm{~cm}^{-1}$ is due to the presence of some adsorbed $\mathrm{CO}_{2}$ at the glass surface [29]. The band around $1628 \mathrm{~cm}^{-1}$ is the deformation mode of O-H-O group attributed to the adsorbed water molecules [30]. Comparatively to 92S6-C7 glass, 92S6-C16 and 92S6-C19 glasses include all above mentioned bands.

In all case the glasses were synthesized using sol-gel method without changing composition. If the composition or the synthesis mode (melting versus sol-gel) change, some differences in the position of vibrations for $\mathrm{SiO}_{4}$ tetrahedrons are observed $[28,31]$. This phenomenon is not observed here and the glass structure is not surfactant-dependent.

\subsection{Bioactivity assays}

\subsubsection{Chemical reactivity investigation}

The formation of a biologically equivalent apatite surface, a common characteristic of bioactive materials, can be reproduced in vitro by immersion experiments using a simulated physiologic fluid (SBF) that mimics the typical ion concentrations in body fluid. We present results of ICP-OES analyses performed on solutions in contact, for different periods, with glasses synthesized using three different surfactants. Fig. 5 shows the evolutions of silicon, 
calcium and phosphorous ionic concentrations, with the soaking time in SBF, for 92S6-C7, 92S6-C16 and 92S6-C19.

As it can be observed, in all cases, variation of Si concentration in the solution was similar for the three samples: an increase up to 57.3 during the first 7 days of immersion and then no significant change. Similarly, variation of $\mathrm{Ca}$ and $\mathrm{P}$ concentration in SBF followed the same tendency for the three glasses. However, these evolutions were different for each glass. For 92S6-C19, Ca and P concentrations reached a maximum after 15 days of soaking in SBF and gradually decreased up to 30 days, while for 92S6-C16 and 92S6-C7 Ca and P concentrations show an increase the first 7 days of soaking, followed by a decrease in concentration. These observations highlight ionic exchanges between the surface material and the surrounding medium, which lead to the formation of the apatite layer. According to Hench, these changes in ionic concentrations demonstrated the dissolution/precipitation process: [32] a hydrated silica layer formed at the surface of bioactive glass prior to the deposition of HA, and these silanol groups $(\mathrm{Si}-\mathrm{OH})$ could be specific sites for apatite nucleation. The variations of $\mathrm{Ca}$ concentration can be explained by $\mathrm{Ca}^{2+}$ ions release from the glass network, and the consecutive apatite layer formation that causes the Ca concentration decrease in SBF.

92S6-C7 and 92S6-C16 glasses have been shown to nucleate hydroxyapatite layer more rapidely than 92S6-C19 glass. This was mainly attributed to the larger surface areas afforded by glasses synthesized with $\mathrm{C}_{7} \mathrm{TMABr}$ and $\mathrm{C}_{16} \mathrm{TMABr}$ surfactants.

\subsubsection{XRD results}

Fig. 6 shows XRD pattern of 92S6 glasses synthesized at C7, C16 or C19 surfactants before and after contact with $\mathrm{SBF}$ for different soaking times at $37^{\circ} \mathrm{C}$. For comparison, X-ray diffraction data of a crystallized hydroxyapatite $(\mathrm{HA}) \mathrm{Ca}_{10}\left(\mathrm{PO}_{4}\right)_{6}(\mathrm{OH})_{2}(\mathrm{Alfa}$, Germany) are also presented. 
For 92S6-C19, X-ray diffraction data (Fig. 6c) show no diffraction peak up to 15 days, suggesting no new phase crystallization at the glass surface during this period. After 21 days, we observe two characteristic peaks of $\mathrm{HA}$ at $25.85^{\circ}$ and $32.02^{\circ}$. After 30 days of soaking in SBF, these two peaks become evident, confirming the formation of a crystalline apatite.

According to XRD results for 92S6-C16 glass (Fig. 6b), no crystalline phase was formed at the glass surface before 15 days. After 15 days, we observe two characteristic peaks of HA at $25.98^{\circ}$ and $31.73^{\circ}$. The intensity of diffraction peaks increased with time up to 30 days.

For 92S6-C7 glass, after 15 days of soaking in the SBF, the XRD diagram (Fig. 6a) reveals the presence of two diffraction peaks located at $25.90^{\circ}$ and $31.99^{\circ}$, corresponding respectively to the (002) and (211) reflection of apatite phase: $\mathrm{Ca}_{10}\left(\mathrm{PO}_{4}\right)_{6}(\mathrm{OH})_{2}$ [33]. This phase increased for 21 and 30 days soaked glasses. After 30 days in SBF, the 92S6-C7 glass pattern shows well-characterized peaks of pure HA.

On the other hand, $\mathrm{XRD}$ results indicate that the glass prepared with $\mathrm{C}_{7} \mathrm{TMABr}$ is more reactive and bioactive than that prepared with $\mathrm{C}_{16} \mathrm{TMABr}$ and $\mathrm{C}_{19} \mathrm{TMABr}$. This result is in good agreement with will be SEM results. This is related to the increase of the nucleation rate.

\subsubsection{Scanning Electron Microscopy}

The samples synthesized with different surfactants were examined with the Scanning Electron Microscopy in order to determine the particles shape.

Fig. 7a, 7c, 7e show the micrographs of the 92S6-C7, 92S6-C16 and 92S6-C19 samples, respectively, before soaking in SBF. The morphological structure result in the formation of spherical mesoporous particles exhibiting a dense and smooth appearance (high coalescence degree), whatever the length of the surfactant tail. It seems that the presence of the cationic surfactant in the reaction favors the formation of spherical particles.

The formation of hydroxyapatite deposition on the glasses surfaces after immersion in SBF was also observed by SEM. 
Fig. $7 \mathrm{~b}, 7 \mathrm{~d}, 7 \mathrm{f}$ show the surface morphology of glasses specimen incubated in SBF for 2 weeks. All mineral coating formed on glasses surface were continuous layers, with differences in microscale morphologies. The surface morphology changed as the length of the surfactant tail increased. 92S6-C7 glass (Fig. 7b) shows the formation of spherical particles coating the whole surface. With increasing the length of surfactant tail to 16, apatite grains (Fig. 7d) were spherical but the density of the micro spherical particles of 92S6-C16 glass was approximately 3 times lower than those of 92S6-C7 glass (Fig. 7b). For 92S6-C19 glass, a layer composed of needle-shaped crystallites covers the surface.

It is well known that the reactivity of solids begins on their surface. The silanol groups (Si$\mathrm{OH})$ on the bioactive glasses surface play an important role in the hydroxyapatite formation [18]. The increase of glass surface specific area favors ionic exchanges, it becomes easier to attract calcium and phosphorous ions on the surfaces of glass, it induces formation of silanol groups and increase the local ions concentrations and consequently improves the nucleation and the growth of bone-like apatite nanocrystals and enhance bone forming bioactivity [34]. Moreover, previous studies showed that the increase of mesopore volume may contribute to the increase of apatite nucleation [20] and porous structures may facilitate the transportation of dissolved $\mathrm{Ca}^{2+}$ ions as well as the subsequent deposition of bone-like hydroxyapatite [35]. So, the clusters and the grains observed at these surfaces are attributed to the formation of phosphate phases (HCA as confirmed by ICP-OES) for all glasses. Furthermore, our results indicate that the thickness of the HCA layer and the spherical particles with needlelike crystallites increase with decreasing the number of surfactant's carbons.

Furthermore, SBF immersion tests reveal that 92S6-C19 glass required 21 days in SBF to form a new apatite phase, indicating the low bioactive behavior of this sol-gel glass. After 30 days in SBF, the surface appears fully covered by crystallites of calcium phosphate characteristic of the growth of apatite phase on a bioactive material surface. However, the use 
of the $\mathrm{C} 7$ or $\mathrm{C} 16$ surfactant induces a formation of apatite layer at the surface after only 15 days of soaking in SBF. Additionally, as it is shown in table 1, lower pore size lead to fast ionic exchanges with surrounding medium, and contribute to a high bioactive feature 92S6-C7 glass. The above results indicate that the 92S6-C7 glass can induce the formation of a HCA layer on its surface faster than 92S6-C16 and 92S6-C19. So, the decrease of pore size may contribute to the increase of apatite nucleation.

In literature data, there were many studies that investigated the effect of synthesis parameters on characteristics and bioactivity of bioactive glass. Mesoporous bioactive glasses with different compositions (100S, 90S5C, 80S15C, 70S25C, 60S35C) have been synthesized and extensively characterized by Yan et al. [26]. By comparing the texture properties and bioactivity of different glasses, authors concluded that the formation mechanism (porecomposition dependence) and bioactivity are different from glass to other. The influence of synthesis method (sol-gel versus melting technique) on the structure, pore morphology and bioactivity of $52 \mathrm{~S} 4$ glass $\left(52 \% \mathrm{SiO} 2,30 \% \mathrm{CaO}, 14 \% \mathrm{Na}_{2} \mathrm{O}, 4 \% \mathrm{P}_{2} \mathrm{O}\right.$ mol \%) was also studied by Mezahi et al. [32]. The in vitro bioactivity of glasses was studied. Authors demonstrated that prepared 52S4 bioactive glass by sol-gel technique has higher bioactivity than those made by melting technique.

So, in our study, we chose to synthesize glasses with a same composition using the same technique (sol-gel), in presence of surfactants with different carbon chain length. Our results showed a direct correlation between the surfactant and textural properties and structural characteristics. We demonstrated that the bioactivity may be significantly modified by a change on surfactant.

\section{Conclusions}

The solids surface reaction is of particular importance in the field of biomaterials, since they will be in contact with an aqueous medium and in presence of cells and proteins. 
This study compares the surface properties and the bioactivity of sol-gel glasses prepared with same composition but with different surfactants. Factors such as the length of carbons chain of the surfactant used in the reaction mixture determine, as it has been shown here, the particle morphology and the porous characteristics of the final mesoporous glasses and then induce bioactivity features.

We have demonstrated here in convincing manner the importance of glasses surface chemistry on the bioactivity: the self assembly of surfactants at the surface can modify the surface properties and thus leads to their many applications.

Our results show that the properties of those glasses are extremely dependent on the properties of the surfactants used as templates in their synthesis.

\section{Acknowledgments}

The authors would like to acknowledge Joseph Le Lannic, from the CMEBA, Universite de Rennes 1, for SEM, and Odile Merdrignac-Conanec, from Laboratoire Verres et Céramiques, Université de Rennes 1, for BET studies.

\section{References}

[1] W. Xia, J. Chang, J. Control. Release. 110 (2006) 522.

[2] H. A. Elbatal, M. A. Azooz, E. M. A. Khalil, A. Soltan Monem, Y. M. Hamdy, J. Mater. Chem. Phys. 80 (2003) 599.

[3] A. Stoch, W. Jastrzebski, A. Brozek, B. Trybalska, M. Cichocinska, E. Szarawara, J. Mol. Struct. 511 (1999) 287.

[4] V. Cannillo, F. Pierli, I. Ronchetti, C. Siligardi, D.Zaffe, Ceram. Int. 35 (2009) 2853.

[5] J.P. Nayak, S. Kumar, J. Bera, J. Non-Cryst. Solids. 365 (2010) 1447.

[6] J. Ma, C. Z. Chen, D. G. Wang, J. Z. Shi, Mater. Sci. Eng., C 30 (2010) 886. 
[7] M. H. Prado da Silva, A. F. Lemos, I. R. Gibson, J. M. F. Ferreira, J. D. Santos, J. NonCryst. Solids. 304 (2002) 286.

[8] I. Elgayar, A. E. Aliev, A. R. Boccaccini, R. G. Hill, J. Non-Cryst. Solids.351 (2005) 173.

[9] J. Andersson, S. Areva, B. Spliethoff, M. Linden, Biomaterials 26 (2005) 6827.

[10] L. Pei. K-I. Kurumada. M. Tanigaki. M. Hiro. K-J. Susa, Mater. Sci. 39 (2004) 4045.

[11] C-Z. Yu, J. Fan, B-Z. Tian, D-Y. Zhao, Chem. Mater. 16 (2004) 889.

[12] X-Y. Bao, X-S. Zhao, X. Li, J. Li, J. Appl. Surf. Sci. 237 (2004) 380.

[13] Y. Bennadja, P. Beaunier, D. Margolese, A. Davidson, Microporous Mesoporous Mater. 147 (2001) 44.

[14] J-W. Tang, C-Z. Yu, X-F. Zhou, X. X. Yan, D. Y. Zhao, Chem. Commun. 175 (2004) 2240.

[15] C-Z. Yu, B-Z. Tian, B. Fan, G-D. Stucky, D-Y. Zhao, Chem. Commun. 133 (2001) 2726.

[16] L-L. Hench, R-J. Splinter, T-K.Greenlee, W-C. Allen, J. Biomed. Mater. Res. 2 (1971) 117.

[17] M. Vallet-Regi, D. Acros, J. Pererz-Pariente, J. Biomed. Mater. Res. 51 (2000) 23.

[18] Á. Szegedi, Z. Kónya , D. Méhn, E. Solymár, G. Pál-Borbély , Z.E. Horváth, L. P. Biró, I. Kiricsi, Appl. Catal., A: General. 272 (2004) 257.

[19] Y. Zhu, C. Wu, Y. Ramaswamy, E. Kockrick, P. Simon, S. Kaskel, H. Zreiqat, Microporous Mesoporous Mater. 112 (2008) 494.

[20] T. Kokubo, H. Hushitani, S. Sakka, S.T. Yamamuro, J. Biomed. Mater. Res. 24 (1990) 721.

[21] J.S. Beck, J.C. Vartuli, W.J. Roth, M.E. Leonowicz, C.T. Kresge, K.D. Schmitt, , C. T.W. Chu, K.H. Olson, E.W. Sheppard, S.B. McCullen, J.B. Higgins, J.L. Schlenker, J. Am. Chem.Soc. 114 (1992) 10834.

[22] V. Luca, D.J. MacLachlan, J.M Hook, R. Withers, Chem.Mater. 7 (1995) 2220. 
[23] L. Sierra, S. Valange, J. Barrault, J.L. Guth, Microporous Mesoporous Mater.113 (2008) 352.

[24] N.K.. Raman, M.T. Anderson, C.J. Brinker, Chem. Mater. 8 (1996) 1682.

[25] P. S. Goyal, V. K. Aswal, Current Science 80 (2001) 972.

[26] X.X. Yan, H.X. Deng, X.H.Huang, G.Q. Lu, S.Z. Qiao, D.Y. Zhao, C.Z. Yu J. NonCryst. Solids. 351 (2005) 3209.

[27] A. Jillavenkatesa, R.A. Condrate, Spec. Lett. 31 (1998) 1619.

[28] A. Lucas-Girot , F. Z. Mezahi, M. Mami, H. Oudadesse, A. Harabi and M. Le Floch. J. Non-Cryst. Solids. 357 (2011) 3322.

[29] S.G. Kazarian, M.F. Vincent, F.V. Bright, C.L. Liotta, C.A. Eckert, J. Am. Chem. Soc. $118(1996) 1729$.

[30] C.Y. Kim, A.E. Clark, L.L. Hench, J. Biomed. Mater. Res. 26 (1992) 1147.

[31] M. Mami, A. Lucas-Girot, H. Oudadesse, R. Dorbez-Sridi, F. Mezahi, E. Dietrich, Appl. Surf. Sci. 254 (2008) 7386.

[32] F.Z. Mezahi, A. Lucas-Girot, H. Oudadesse, A. Harabi, J. Non-Cryst. Solids. 361 (2013) 111.

[33] Powder diffraction File, No. 09-0432, JCPDS, International Centre for Diffraction Data, 2002.

[34] D. Zhao, J. Feng, Q. Huo, N. Melosh, G.H. Fredrickson, B.F. Chmelka, G.D. Stucky, Science 279 (1998) 548.

[35] X. Yan, C. Yu, X. Zhou, J. Tang, D. Zhao, Angew. Chem, Int. Ed. Engl. 43 (2004) 5980.

Fig. 1. SAXRD patterns of powders of 92S6-C7, 92S6-C16 and 92S6-C19 glasses surfaces before soaking in SBF solution. 
Fig. 2. WAXRD patterns of different glasses before soaking in SBF solution.

Fig. 3. $\mathrm{N}_{2}$ adsorption/desorption isotherms of (a) 92S6-C7, (b) 92S6-C16 and (c) 92S6-C19.

Fig. 4. FTIR spectra of prepared glasses: 92S6-C7 (a), 92S6-C16 (b) and 92S6-C19 (c).

Fig. 5. Evolution of $\mathrm{Si}(\mathrm{a}), \mathrm{Ca}(\mathrm{b})$ and $\mathrm{P}$ (c) concentrations in SBF, versus soaking time for 92S6-C7, 92S6-C16 and 92S6-C19 glasses.

Fig. 6. WAXRD patterns of glass surfaces before and after different soaking times in SBF solution: 92S6-C7 (a), 92S6-C16 (b) and 92S6-C19 (c).

Fig. 7. SEM micrographs of bioactive glasses (a,b) 92S6-C7, (c,d) 92S6-C16 and (e,f) 92S6C19 surfaces before (x 50000) and after soaking for 2 weeks in SBF solution (x 20000).

Table 1

Textural properties of sol-gel glasses synthesized with different length of the carbon chain template.

\begin{tabular}{lccc}
\hline Samples & $\mathrm{S}_{\mathrm{BET}}{ }^{\mathrm{a}}\left(\mathrm{m}^{2} / \mathrm{g}\right)$ & $\mathrm{Vp}^{\mathrm{b}}\left(\mathrm{cm}^{3} / \mathrm{g}\right)$ & $\mathrm{D}_{\mathrm{p}}{ }^{\mathrm{c}}(\mathrm{nm})$ \\
\hline 92S6-C7 & 248 & 0.28 & 2.6 \\
92S6-C16 & 224 & 0.16 & 4.85 \\
92S6-C19 & 88 & 0.13 & 8.24 \\
\hline
\end{tabular}

${ }^{a}$ BET specific surface area.

${ }^{\mathrm{b}}$ Pore volume.

${ }^{\mathrm{c}}$ Pore diameter calculated by BJH method. 


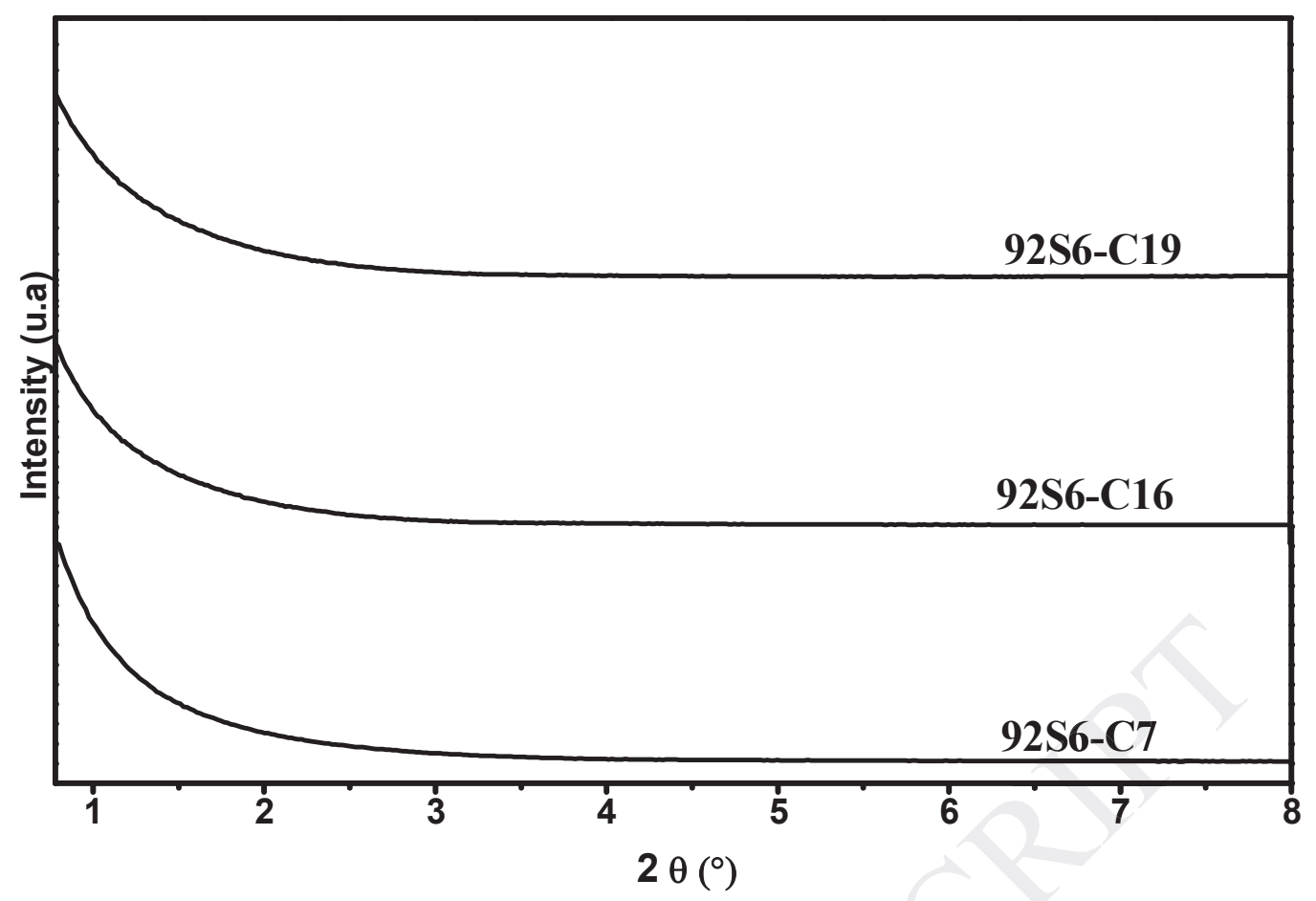

Fig. 1.

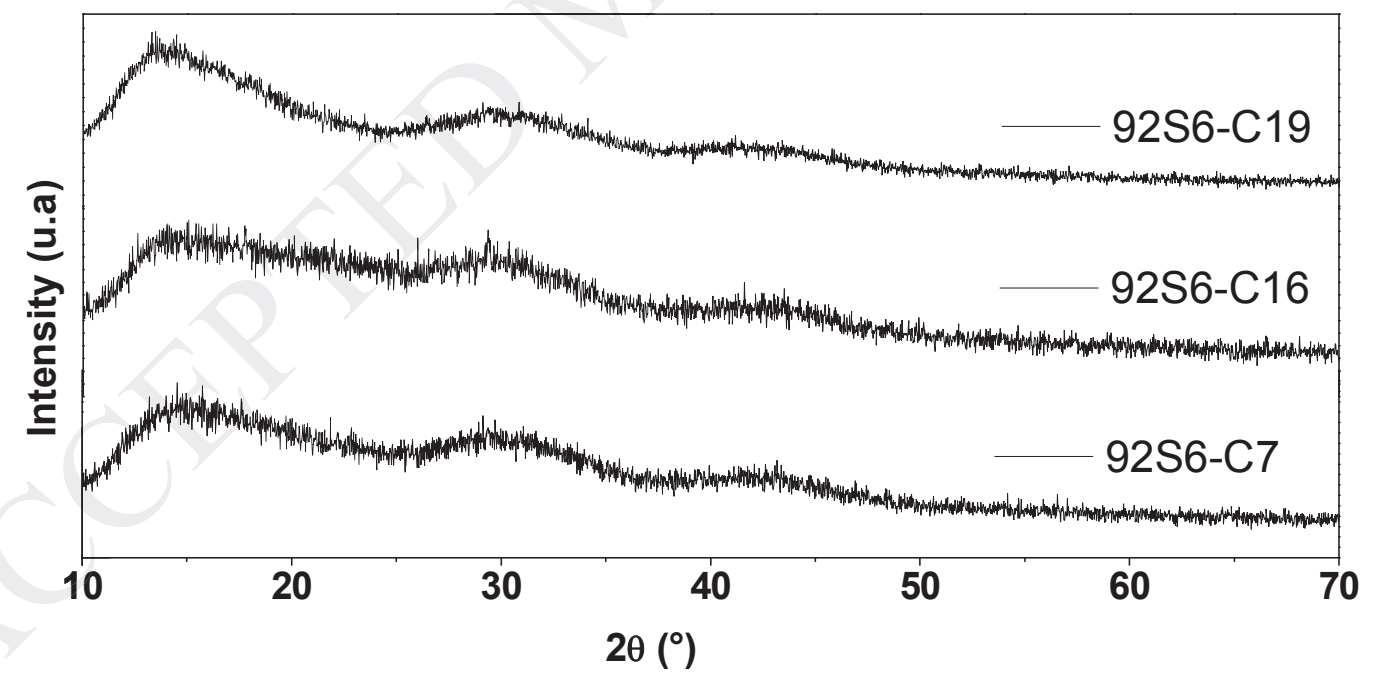

Fig. 2. 

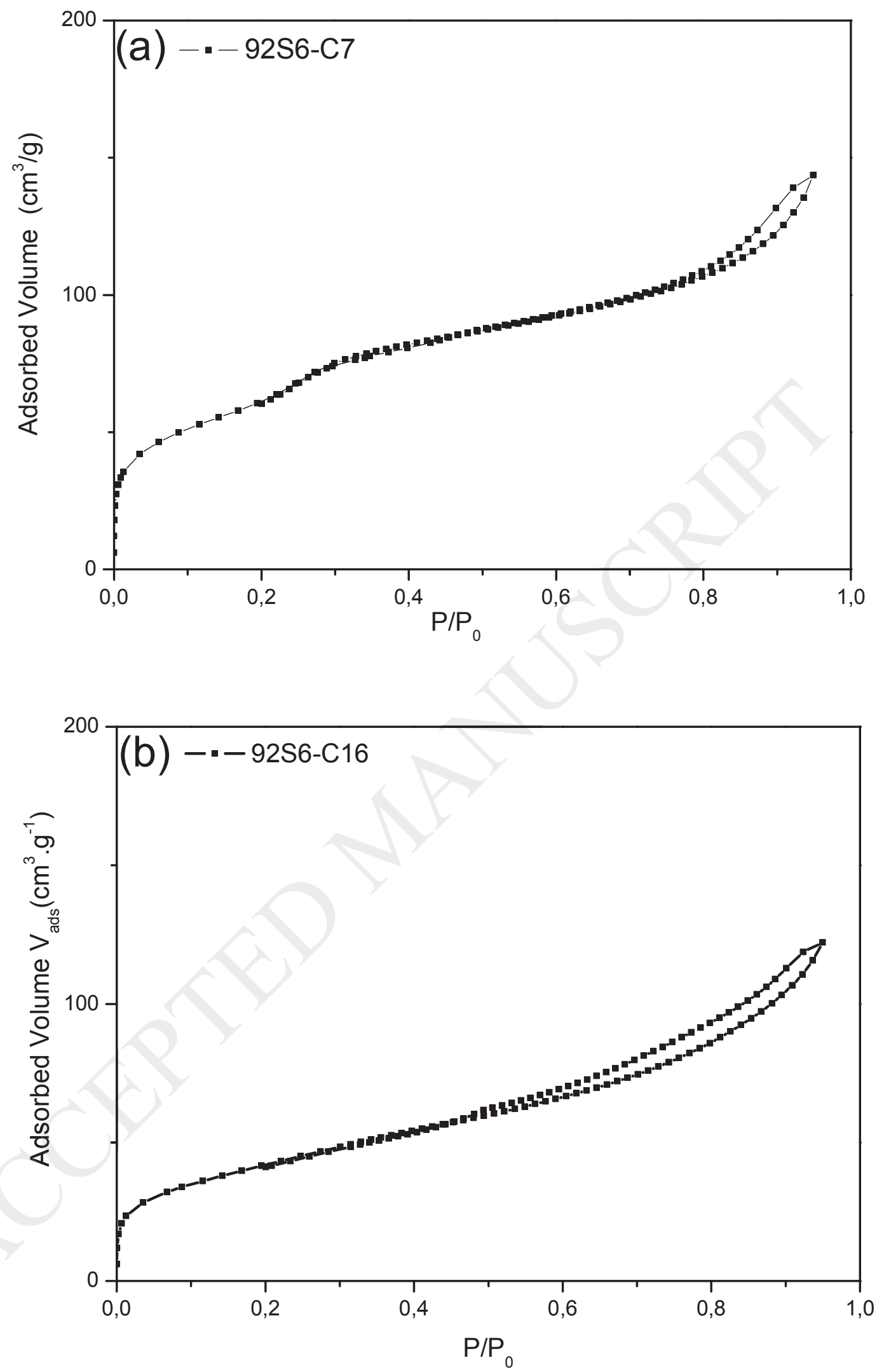


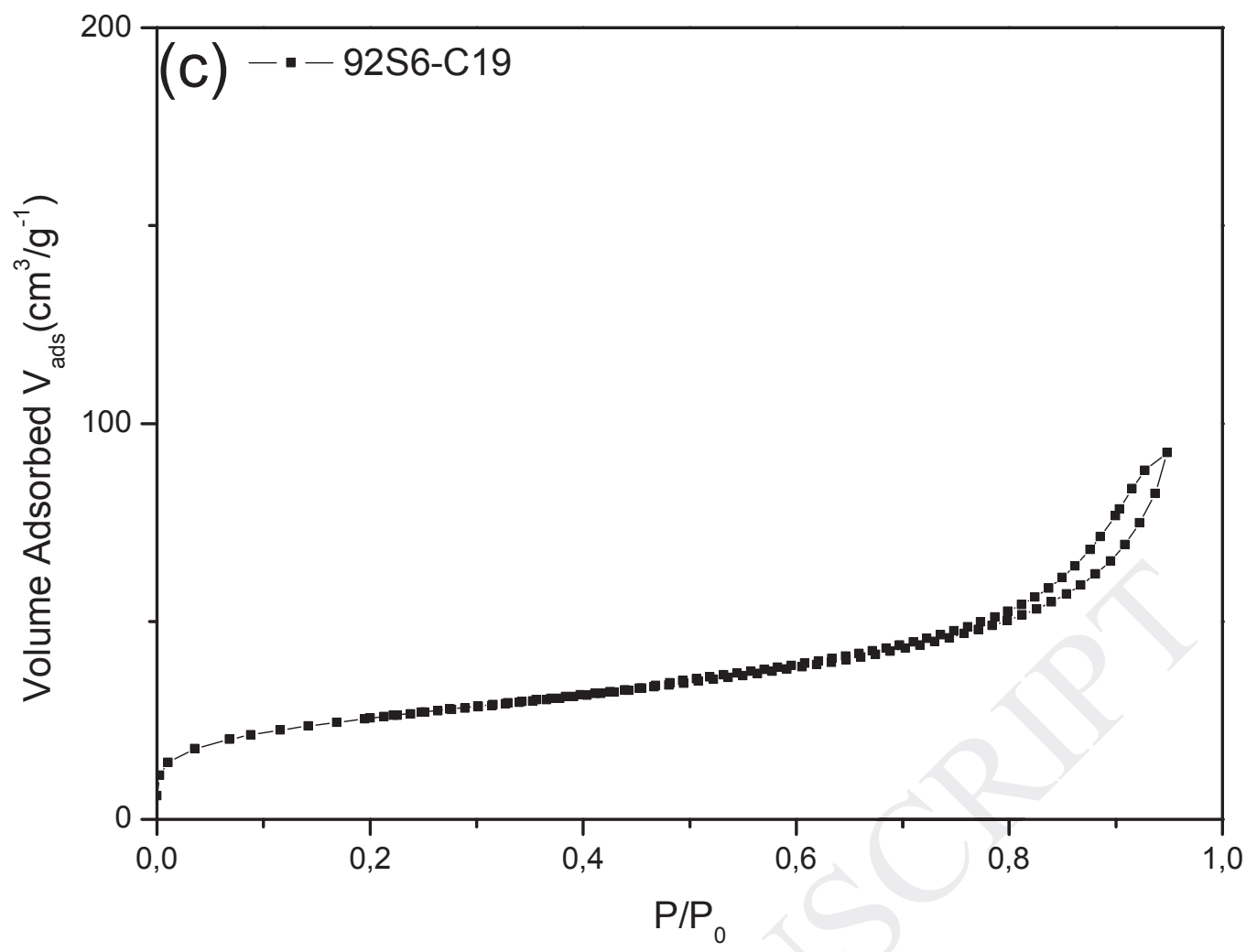

Fig. 3.

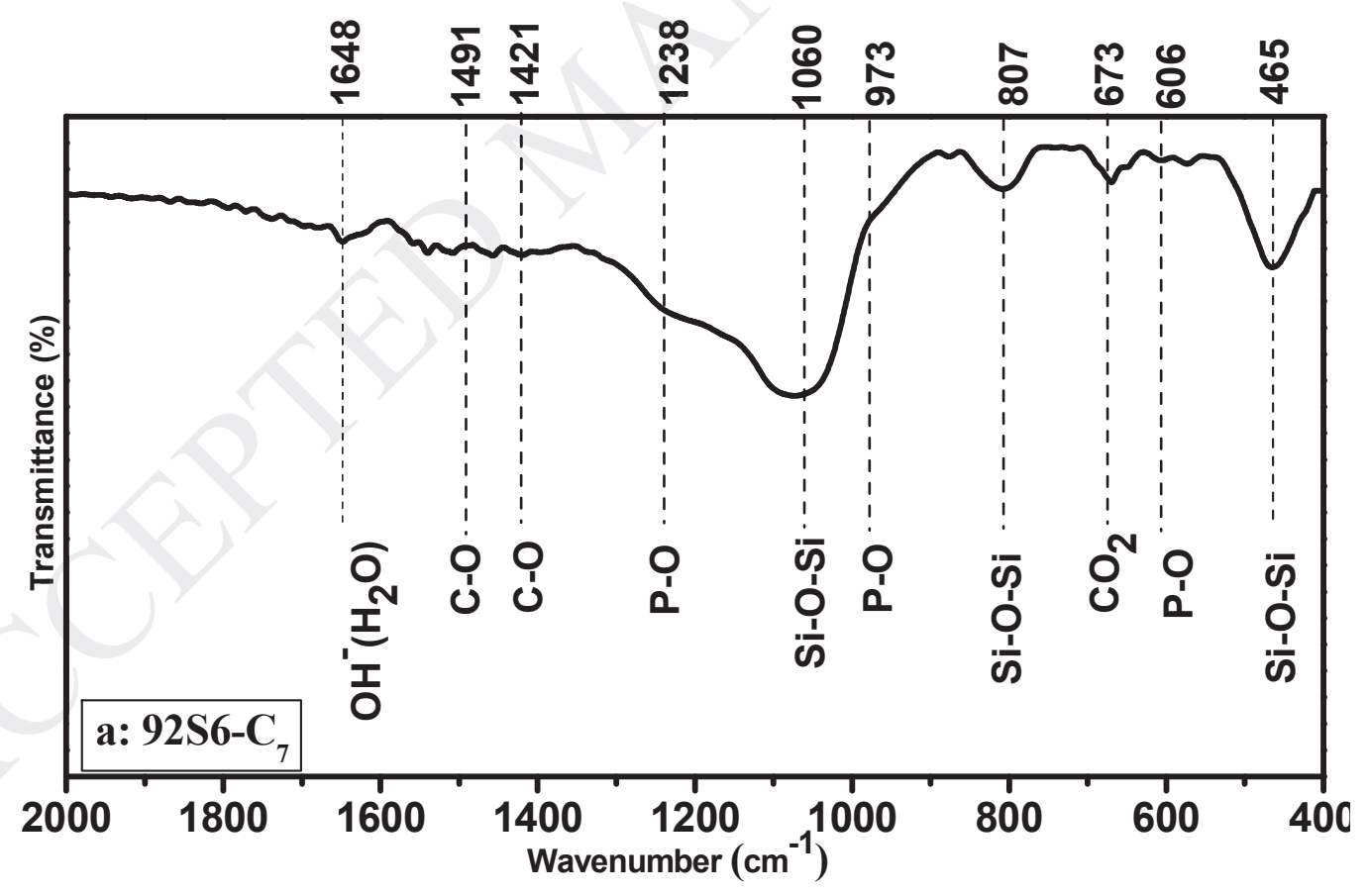



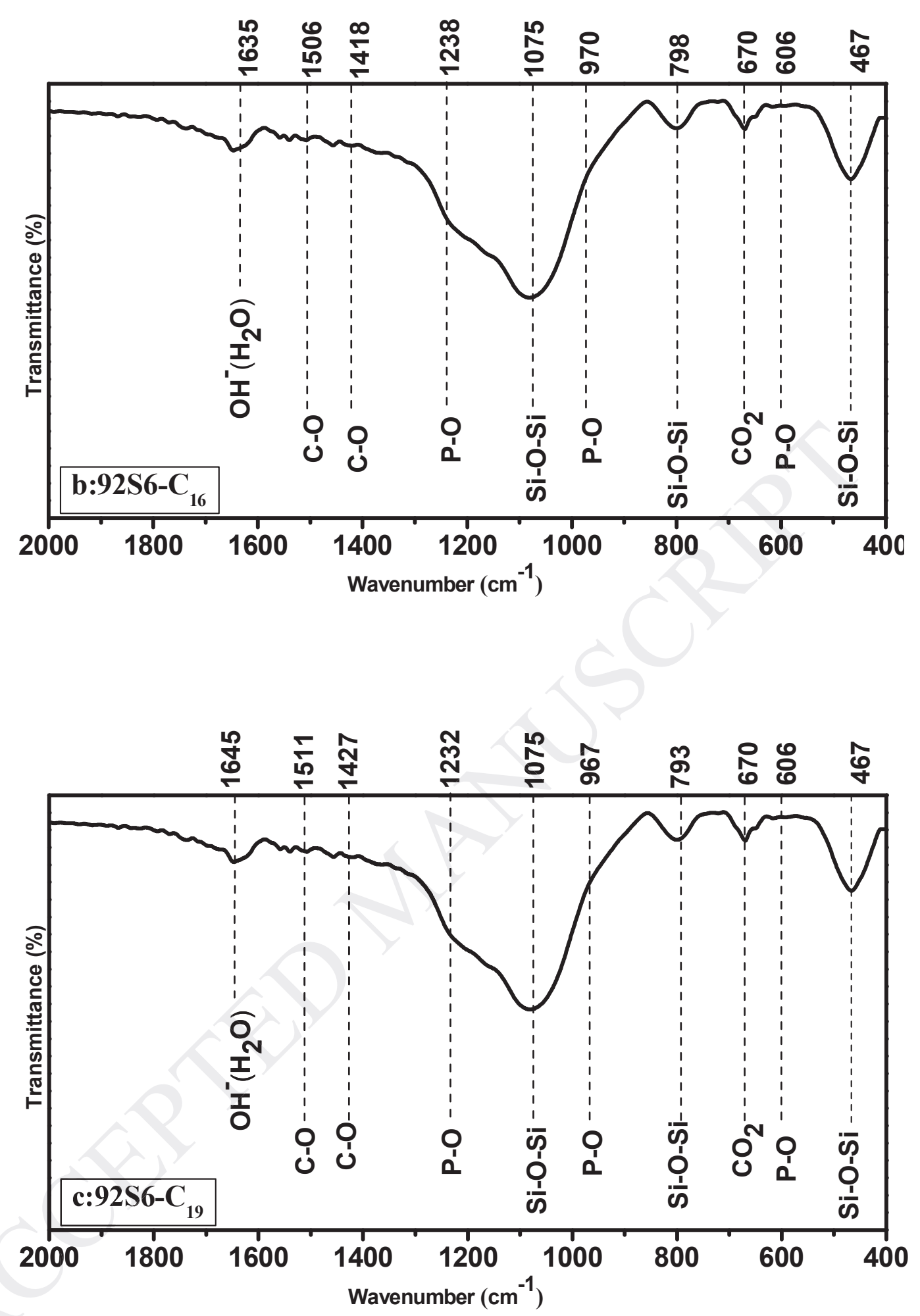

Fig. 4. 
(a)

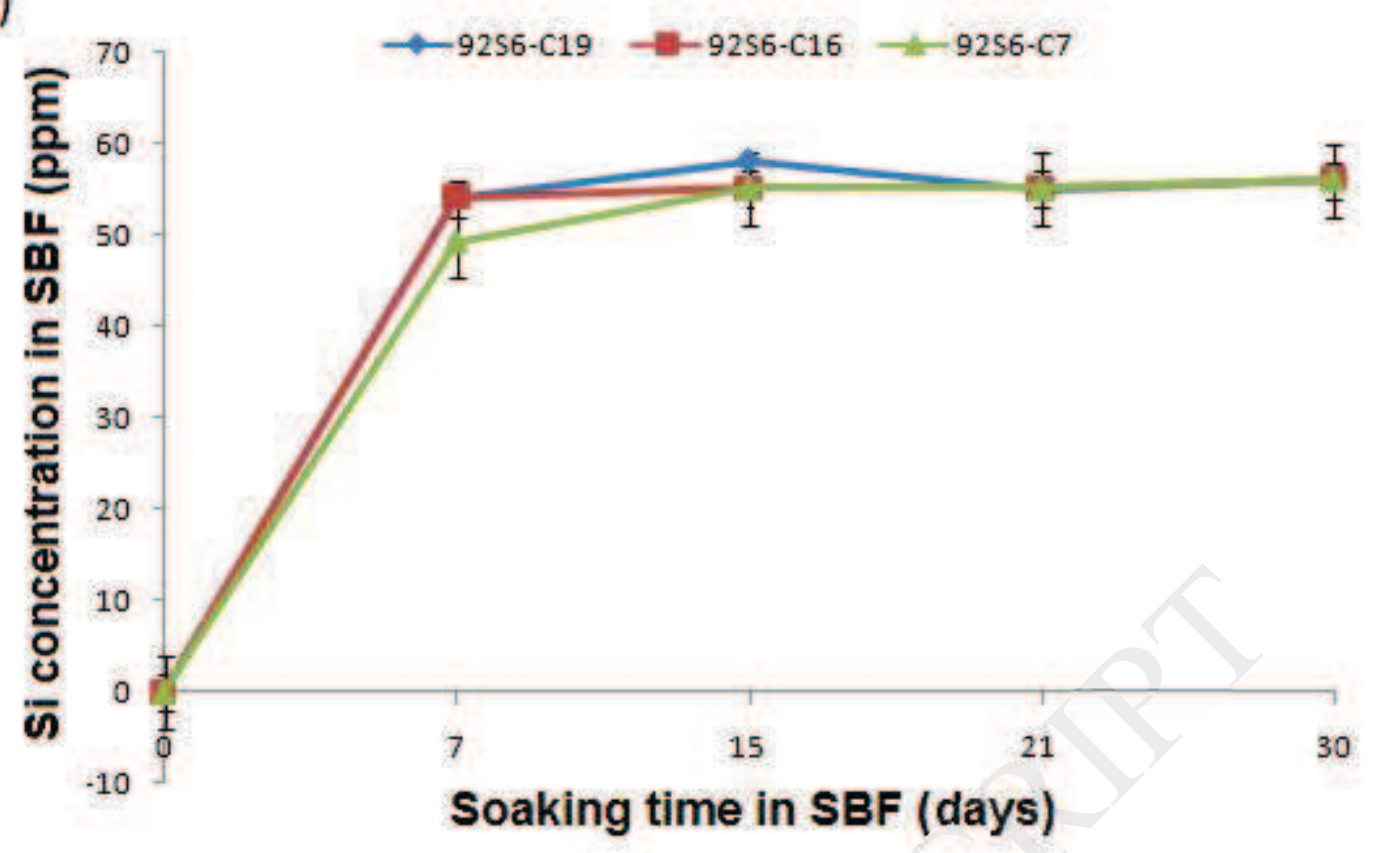

(b)

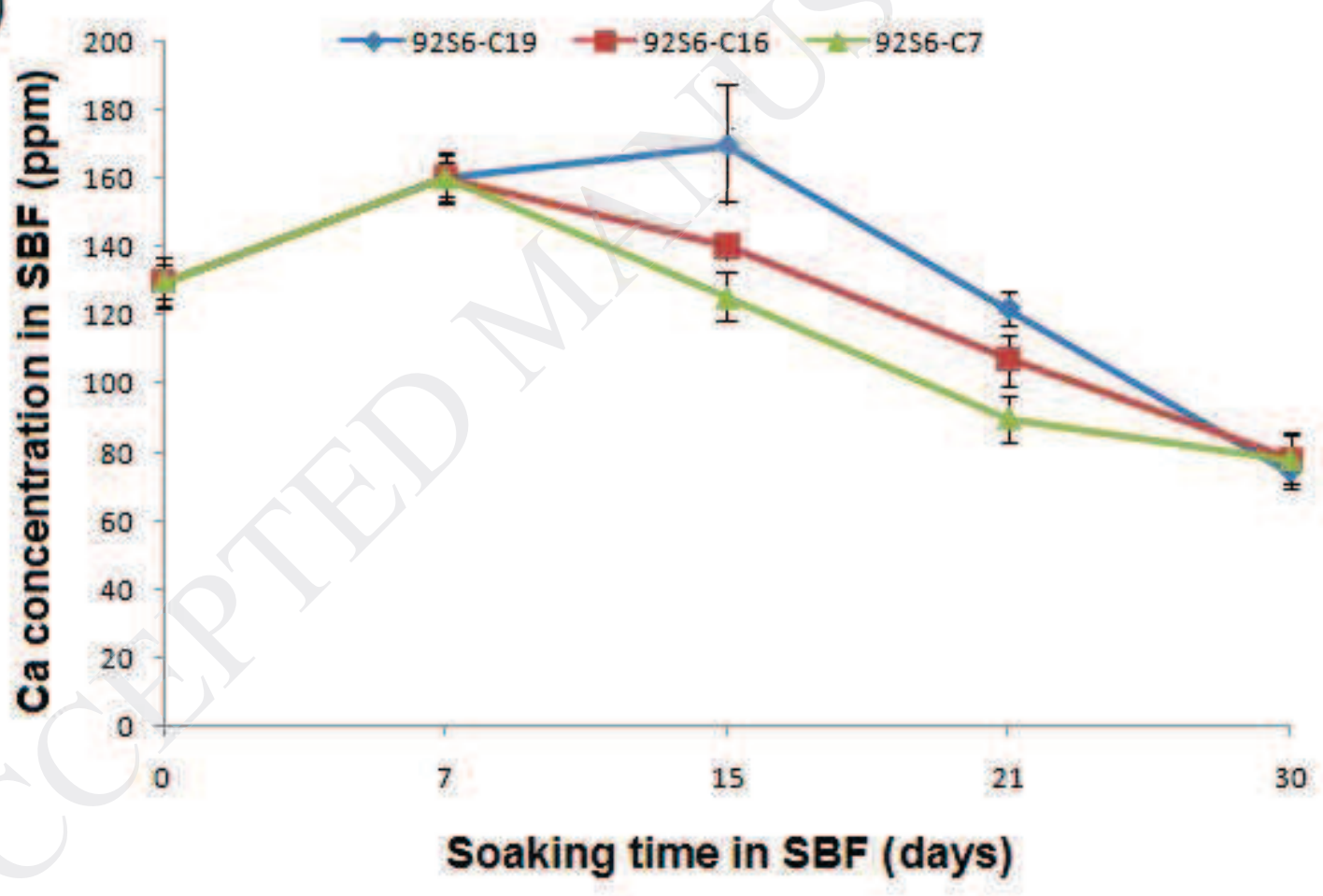


(c)

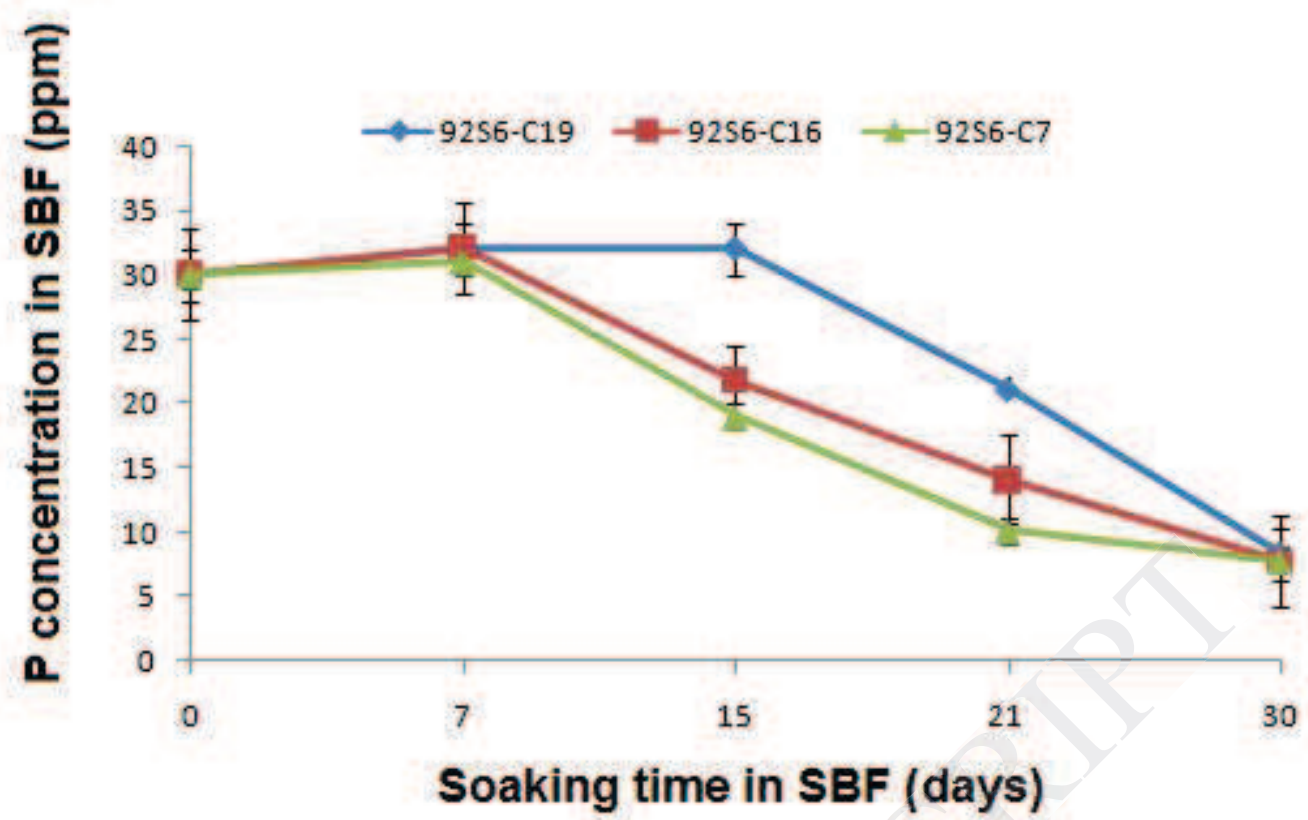

Fig. 5.

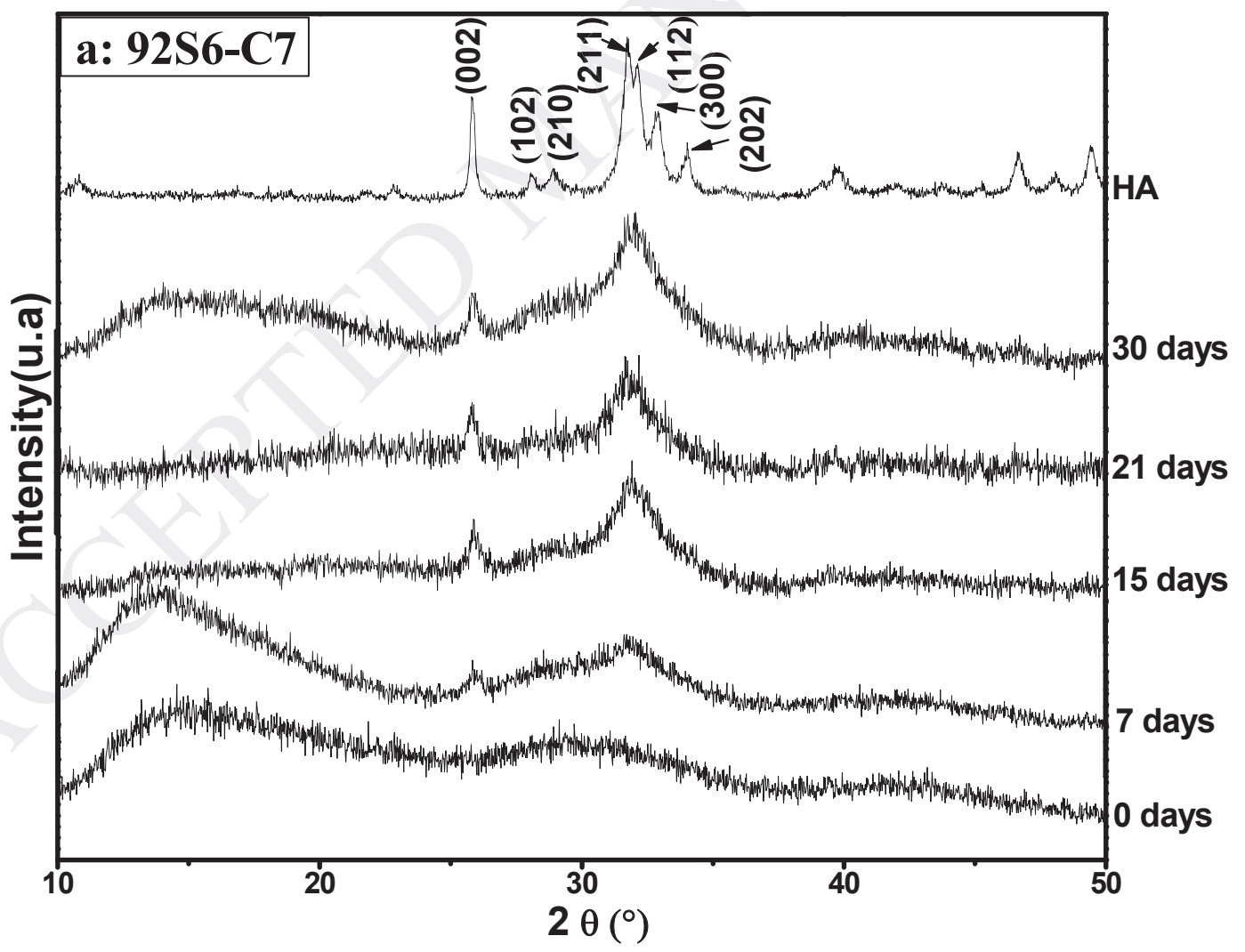



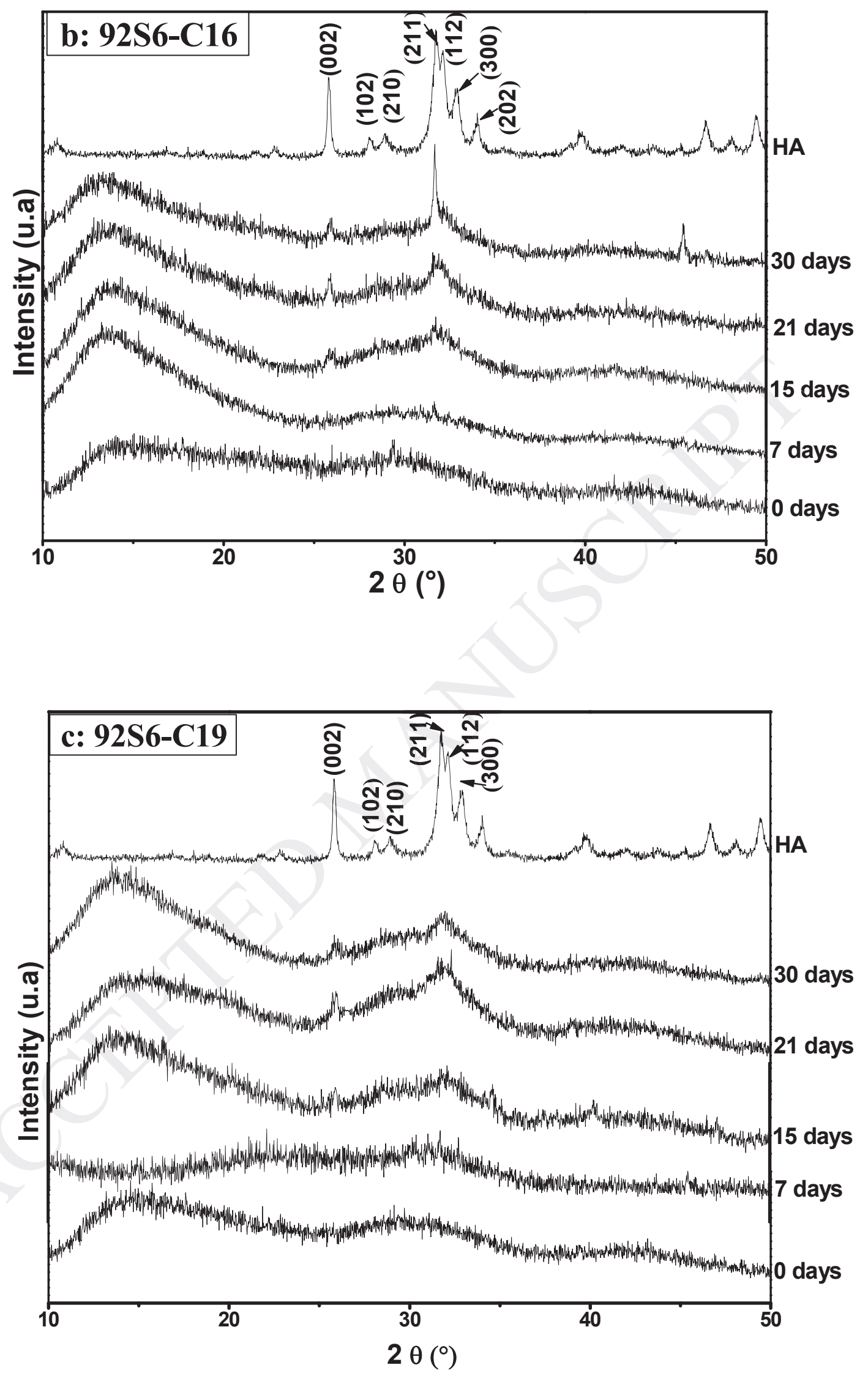
Fig. 6.

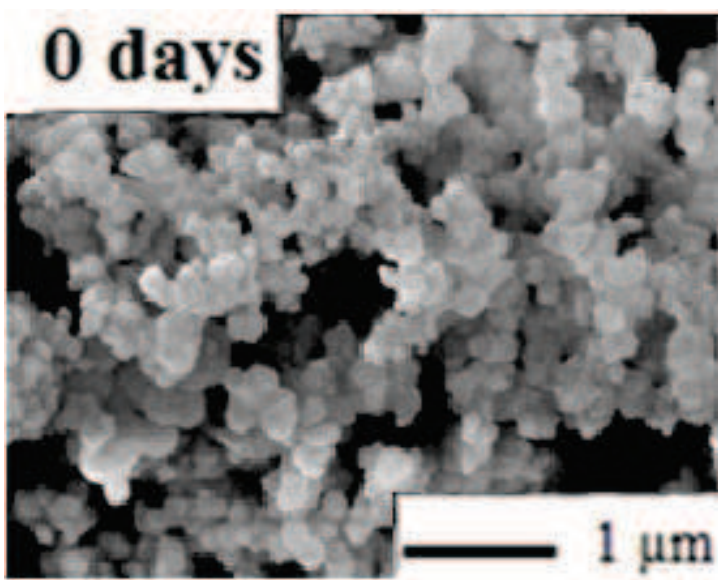

(a)

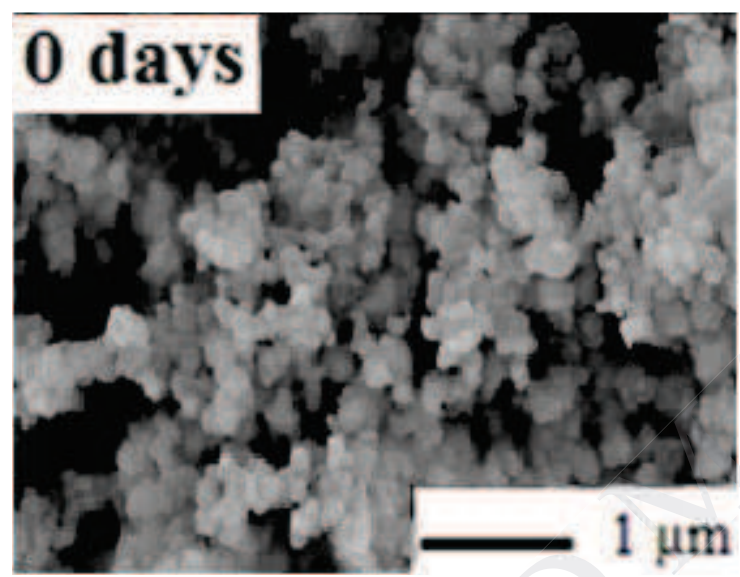

(c)

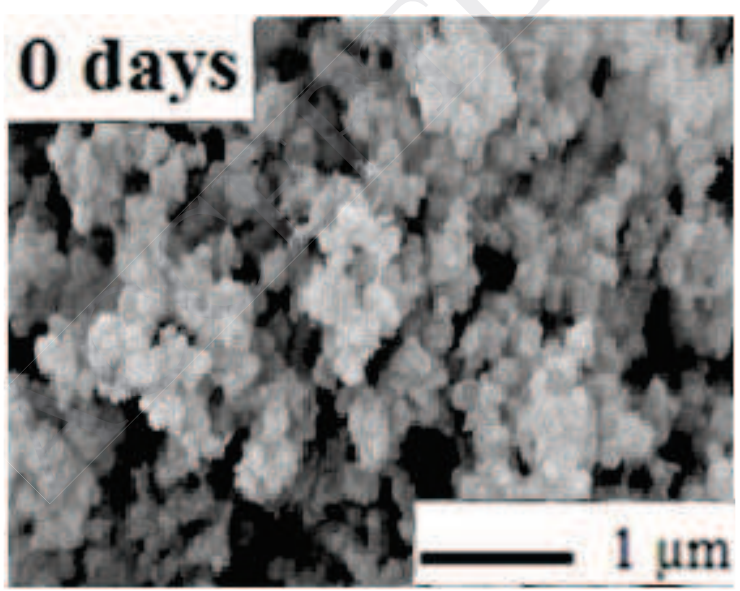

(e)

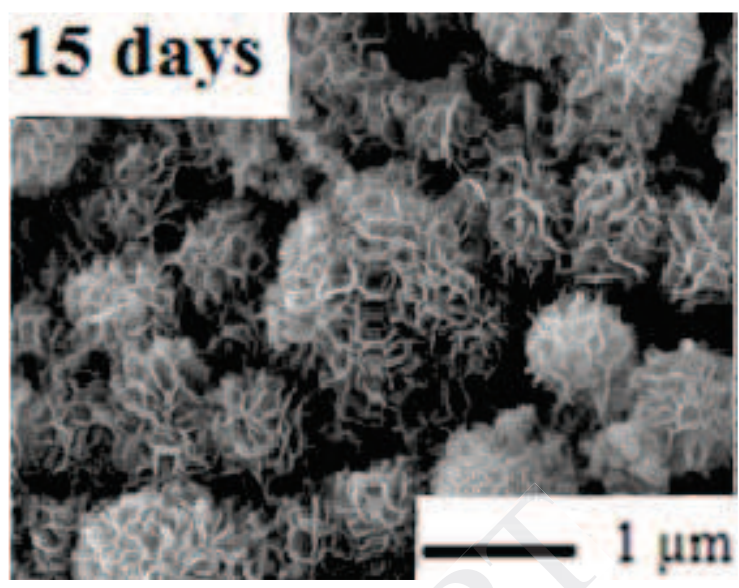

(b)

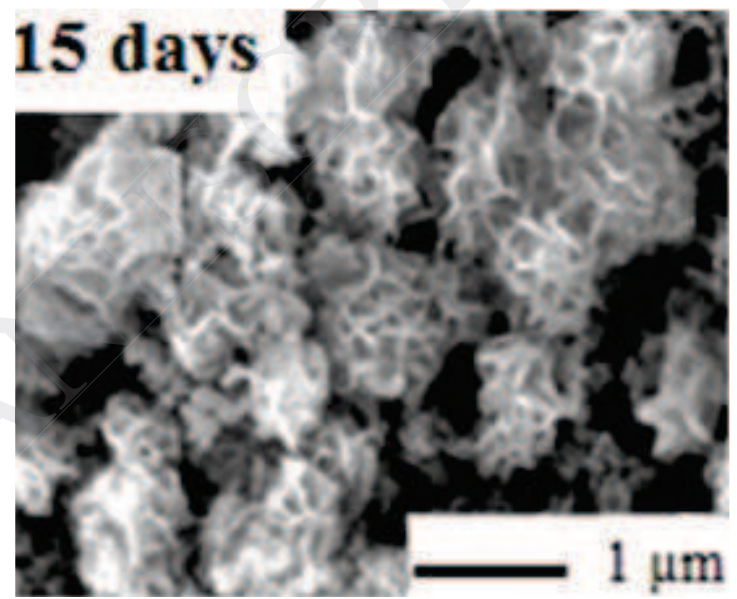

(d)

\section{5 days}

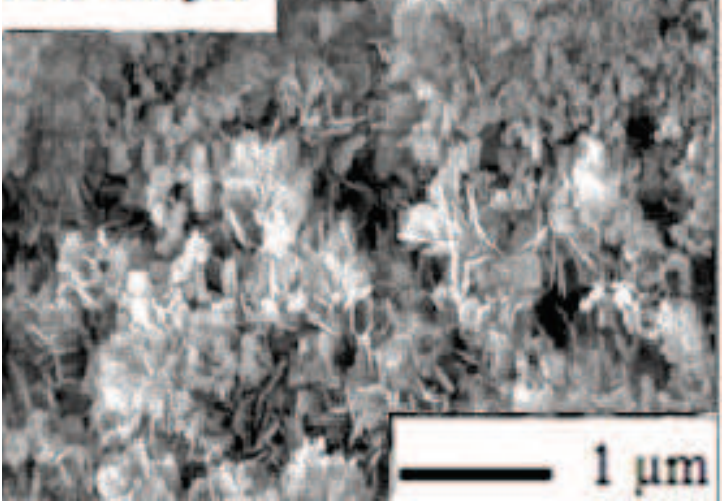

(f)

Fig. 7. 